\title{
Artikel
}

\section{Zorgen rondom het strafrecht: TBS}

\author{
Problemen in de praktijk en een imagoprobleem: het perspectief van de terbeschikkinggestelde
}

Mr. J.A.W. (Job) Knoester en mr.dr. J. (Jan) Boksem*

\section{Inleiding}

TBS (de maatregel van terbeschikkingstelling) is zowel dienstbaar aan de behandeling van de veroordeelde als aan terugkeer van de terbeschikkinggestelde in de samenleving. ${ }^{1}$ Het karakter van de TBS-maatregel wordt hierbij in acht genomen. De wet is duidelijk: als vrijheden aan een terbeschikkinggestelde worden verleend wordt rekening gehouden met de veiligheid van de samenleving en de belangen van slachtoffers en nabestaanden. TBS wordt primair gezien als een beveiligingsmaatregel. Van belang is dat aan terbeschikkinggestelden geen andere beperkingen worden opgelegd dan die voor het doel van de TBS of in het belang van de orde en veiligheid in de kliniek noodzakelijk zijn. ${ }^{2}$

De TBS komt ook daadwerkelijk aan de doelstellingen tegemoet. Dat tonen op cijfers gebaseerde feiten al jarenlang aan. Terbeschikkinggestelden vallen drie tot vier keer minder in herhaling dan mensen die onbehandeld uit de gevangenis komen. Toch lijkt er veel onduidelijkheid in de samenleving over de behandelmaatregel te bestaan. Dat heeft irreële kanten. Samenleving en politiek waren in oktober 2017 woedend toen bleek dat Michael P. verdacht werd van de moord op en verkrachting van Anne Faber. De boosheid zag erop dat P. in 2012 voor twee verkrachtingen geen TBS had gekregen. TBS zou de dood van Anne Faber hebben kunnen

Job Knoester is strafrechtadvocaat bij KVAK advocaten en tevens voorzitter van de Vereniging van tbs-Advocaten. Jan Boksem is strafrechtadvocaat bij Anker \& Anker Strafrechtadvocaten.

1. Art. 2 lid 1 Beginselenwet verpleging terbeschikkinggestelden.

2. Art. 2 lid 2 Beginselenwet verpleging terbeschikkinggestelden. voorkomen, zo was de teneur. Begin 2019 richtte de kritiek zich juist op de TBS toen een terbeschikkinggestelde en een oud-terbeschikkinggestelde werden aangehouden op verdenking van de moord op een 72-jarige man in Lelystad. Er gingen stemmen op om het verlof of zelfs de TBS als zodanig af te schaffen.

Die onrust zien ook verdachten. Zij willen TBS ontlopen. Terbeschikkinggestelden klagen regelmatig over de lange duur van de maatregel, personeelstekorten en veel verloop van behandelaren met een trage behandeling tot gevolg en stilstand in de behandeling na een incident.

In deze bijdrage staan wij stil bij een aantal kwesties die het succes van de TBS-maatregel (kunnen) ondermijnen. Voor een deel gaat het daarbij om praktische problemen die met enige goede wil zouden kunnen worden weggenomen, en voor een ander deel gaat het om een imagoprobleem waarvoor - naast goede informatieverstrekking aan verdachten, terbeschikkinggestelden en aan de samenleving - wellicht een meer structurele ingreep noodzakelijk is. Bij de bespreking van de verschillende thema's hebben wij het perspectief van de terbeschikkinggestelde als uitgangspunt genomen.

Over de TBS valt veel te zeggen. Wij kunnen in deze bijdrage onmogelijk volledig zijn. Dat is ook niet ons streven. Met deze bijdrage willen wij slechts aandacht vragen voor een maatregel die in potentie veel te bieden heeft (voor zowel de tot TBS veroordeelde als voor de samenleving), maar die door beslissingen die worden genomen en door keuzes die zijn of worden gemaakt, niet optimaal functioneert. Naast de onderwerpen die in onze bijdrage aan de orde komen, laten we veel kwesties onbesproken of stippen ze slechts kort aan. Zo gaan wij bijvoorbeeld niet (nader) in op: 
- de mogelijkheid van contra-expertise na observatie in het Pieter Baan Centrum;

- de TBS met voorwaarden;

- de gemaximeerde TBS;

- de consequenties van de toekomstige VI-regeling;

- plaatsing en overplaatsing van terbeschikkinggestelden;

- de wachttijd voor TBS-passanten;

- het ontbreken van de mogelijkheid van compensatie voor (langdurig) verblijf in voorlopige hechtenis;

- gespecialiseerde klinieken of afdelingen;

- trage behandeling;

- libido-remmers bij zedendelinquenten;

- dwangmedicatie;

- verlofbeslissingen door de Minister - incidentenpolitiek - onafhankelijke verlofcommissie;

- de waarde van risicotaxatie-instrumenten - delictgevaar;

- tussentijdse toetsing door de rechter;

- (toetsing van) trajectbeslissingen door de rechter;

- verlengingsadvies (altijd) door externe deskundigen;

- voorwaardelijke beëindiging in plaats van de lange weg via proefverlof;

- de rol van de reclassering;

- toevoeging van de raadsman voor werkzaamheden die samenhangen met de inhoud/voortgang van de behandeling;

- onterechte verlengingen (wegens gebrek aan vervolgvoorzieningen);

- etc.

Wij zullen hieronder achtereenvolgens ingaan op: de oplegging van TBS (combinatie gevangenisstraf en TBS), de fase na de uitspraak (passantenproblematiek), de behandeling (personeelsproblemen, stilstand na incident), uitstroom of niet (zorgconferenties) en het imago van de TBS. We sluiten af met een aantal aanbevelingen.

\section{Problemen in de praktijk}

\subsection{Combinatie gevangenisstraf en TBS}

Rechters leggen in toenemende mate lange gevangenisstraffen op in combinatie met TBS. ${ }^{3}$ Hier zit een groot nadeel aan. Als rechters vaststellen dat iemand lijdt aan een stoornis en oordelen dat een TBS-behandeling noodzakelijk is, kan de vraag worden gesteld waarom die behandeling moet worden uitgesteld. Iemand met een hartkwaal laten we ook niet eerst een marathon lopen voordat hij wordt geopereerd. Op 22 december 2014 deed de Taskforce behandelduur TBS, onder leiding

3. Auteur, journalist en eigenaar van de website Moordatlas, Eric Slot, deed onderzoek naar de combinatie van lange gevangenisstraffen en TBS. Zijn bevindingen worden later gepubliceerd. Hij concludeert dat er tussen 1960 en 1999 acht keer een gevangenisstraf van twintig jaar of meer in combinatie met TBS werd opgelegd en tussen 2000 en 2020 twintig keer. Opmerkelijk is in dit verband dat het aantal moorden in de laatstgenoemde periode is gehalveerd. De gemiddelde strafduur is in laatste jaren echter aanzienlijk langer dan in de vorige eeuw. van Bas Eenhoorn, diverse ketenpartners in het TBSveld een aantal aanbevelingen. ${ }^{4}$ Een van die aanbevelingen was dat getracht moet worden detentieschade te voorkomen. De taskforce stelde vast dat gedragsdeskundigen van oordeel zijn dat uitstel van behandeling geen positief effect heeft op het psychiatrisch ziektebeeld van terbeschikkinggestelden. Volgens de taskforce kan het voorkomen van detentieschade en een betere voorbereiding op de behandeling in het kader van de TBS op een drietal manieren worden bereikt. In de eerste plaats kregen rechters het advies terughoudend te zijn bij het opleggen van lange detentie in combinatie met TBS. In de twee plaats werd de rechterlijke macht geadviseerd om - als de specifieke omstandigheden daarom vragen - in combinatievonnissen gebruik te maken van de mogelijkheid te adviseren de behandeling eerder dan gebruikelijk te laten ingaan. ${ }^{5}$ In de derde plaats achtte de taskforce het belangrijk dat veroordeelden tijdens detentie beter worden voorbereid op en gemotiveerd worden voor de TBS-behandeling.

Genoemde adviezen lijken (vooralsnog) geen opvolging te hebben gekregen. De taskforce stelde al vast dat de duur van gevangenisstraffen die aan TBS voorafgaan aanzienlijk was gestegen. Dat is de laatste jaren bepaald niet minder geworden: integendeel. Dat is niet alleen schadelijk voor de terbeschikkinggestelde zelf, maar ook voor het stelsel als zodanig. De taskforce wees erop dat men zich moet realiseren dat lange detentie de behandelduur van de TBS zal opdrijven. Dat levert niet alleen een slecht imago voor TBS op, maar veroorzaakt ook problemen in de doorstroom.

Adviezen van rechters om TBS eerder te laten ingaan zijn volgens de taskforce alleen een reële mogelijkheid bij het opleggen van een gevangenisstraf tot maximaal zes jaar. Als de behandeling verlof nodig makt, is dat op zijn vroegst mogelijk als het moment van de vervroegde invrijheidstelling is bereikt.

Tot slot valt er nog veel winst te behalen in de voorbereiding op opname in TBS-klinieken. Momenteel is er in Nederland slechts één pre-TBS-afdeling in het gevangeniswezen. Deze, in de PI Vught gehuisveste, afdeling stelt niet meer dan een handvol tot TBS veroordeelden in staat een pre-behandeling te ondergaan.

\subsection{Passantenproblematiek}

In 2013 voerde toenmalig Staatssecretaris Teeven een zogenoemd 'masterplan' uit. Onderdeel hiervan was de sluiting van drie TBS-klinieken. In die periode was er sprake van overcapaciteit, maar de sector waarschuwde ervoor dat dat tijdelijk was. Het viel te verwachten dat er een periode zou komen dat meer aanspraak op behandeling zou moeten worden gedaan. Er is door de loop van de jaren sprake van golfbewegingen. Door de sluiting van de drie klinieken vertrok ervaren personeel

4. Rapportage Taskforce behandelduur TBS 22 december 2014 www.vgn.nl/documenten/rapportage-taskforce-behandelduur-tbs.

5. Art. 37b lid $2 \mathrm{Sr}$. 
en ging deskundigheid verloren. Vanaf 2017 steeg het aantal jaarlijkse TBS-opleggingen in vergelijking met de tien jaar daarvoor. Inmiddels hebben nagenoeg alle TBS-klinieken wachtlijsten, waardoor de problemen in de doorstroom in de TBS-behandeling al starten voor de behandeling daadwerkelijk is aangevangen.

Als terbeschikkinggestelden langer dan vier maanden moeten wachten op opname in een kliniek ontstaat er recht op schadevergoeding ${ }^{6}$ van de Staat. Het CJIB gaat - voordat tot vergoeding wordt overgegaan - na of de betrokkene openstaande boetes heeft of dat er sprake is van schadevergoedingsmaatregelen waarmee moet worden verrekend.

\subsection{Personeelsproblemen}

TBS-klinieken kampen regelmatig met personeelstekorten en/of met (veel) verloop in de behandelteams. De klinieken doen er veel aan gekwalificeerd personeel te werven, maar dit probleem doet zich al jaren voor en is niet zomaar opgelost. Het probleem is ernstig. Veel terbeschikkinggestelden vinden het moeilijk hun ziel en zaligheid bij behandelaren bloot te geven. Vertrouwen is van belang en dat kan niet zonder continuïteit. Een ander probleem ontstaat als wisseling van behandelaren leidt tot nieuw beleid. Ook dat raakt de continuiiteit en geeft vertraging.

\subsection{Stilstand na incident}

Een verlofmachtiging vervalt zodra een terbeschikkinggestelde vierentwintig uur ongeoorloofd afwezig is of als het Openbaar Ministerie de directeur van een TBS-kliniek meldt dat de terbeschikkinggestelde verdachte is ter zake een strafbaar feit waarvoor voorlopige hechtenis is toegelaten. ${ }^{7}$ Van belang is in dit verband dat de kliniek geen keuze heeft. Er is een verplichting aangifte te doen als het gaat om een strafbaar feit waarvoor voorlopige hechtenis is toegelaten en dit feit begaan zou zijn tijdens de TBS-maatregel.

De stilstand wordt helemaal een groot probleem nu een jaar lang geen nieuwe verlofmachtiging wordt verleend als de terbeschikkinggestelde is aangemerkt als verdachte van een dergelijk strafbaar feit. ${ }^{8}$ Hiervan kan overigens worden afgeweken als een sepot, een transactie, strafbeschikking of vrijspraak is gevolgd en die beslissing onherroepelijk is geworden. Hier ligt een belangrijke taak voor de raadsman om er bovenop te zitten, aangezien de meeste aangiften uiteindelijk niet tot strafoplegging leiden.

Bijkomend probleem is dat het Openbaar Ministerie strafzaken tegen terbeschikkinggestelden regelmatig niet voortvarend ter hand neemt. Advocaten kunnen dan via artikel 180 Wetboek van Strafvordering (Sv) de rechtercommissaris inschakelen zodat die kan waken tegen

6. Zie HR 21 december 2007, ECLI:NL:HR:2007:BB5074.

7. Art. 15 Verlofregeling jo. art. 53 lid 2 onder 1 en onder 2 en 57 lid 4 onder 1 en 2 Reglement verpleging terbeschikkinggestelden.

8. Art. 17 lid 1 Verlofregeling. nodeloze vertraging in het opsporingsonderzoek, maar ook een dergelijke procedure kost in de regel veel tijd.

Het verlof wordt eveneens een jaar opgeschort als de terbeschikkinggestelde langer dan vierentwintig uur ongeoorloofd afwezig is geweest. ${ }^{9}$

De genoemde regelgeving creëert problemen als de kliniek binnen het jaar dat geen verlof mag worden verleend het incident met de terbeschikkinggestelde heeft geanalyseerd, en indien nodig het risicomanagement daarop werd aangepast, en men tot de conclusie is gekomen dat het behandeltechnisch van belang is dat het verlof eerder dan dat jaar (al dan niet in aangepaste vorm) weer wordt opgestart. Ook dit levert ernstige problemen op in de doorstroom van het behandeltraject.

Tijdens het werkcongres over TBS 'Lunteren IV' vertelde oud-Staatssecretaris Teeven dat de wetgeving rond het zogenoemde Teeven-jaar het gevolg was van incidenten en de politieke drang te laten zien dat er werd opgetreden. Behandelaren en terbeschikkinggestelden ervaren deze regelgeving regelmatig als onnodig en belemmerend in de behandeling. Het is juist dit soort incidentenwetgeving die maakte dat de Raad voor Strafrechttoepassing en Jeugdbescherming (RSJ) op 30 april 2020 in zijn rapport Langdurig in tbs de aanbeveling deed de directe verantwoordelijkheid van de minister bij verlof te heroverwegen om de politieke druk te laten afnemen. Op die manier bestaat de hoop dat incidenten niet elke keer tot debatten in de Tweede Kamer leiden met op incidenten gebaseerde regelgeving tot gevolg die het grotere geheel kunnen schaden. ${ }^{10}$ In 2006 deed de Commissie-Visser al dezelfde aanbeveling. ${ }^{11}$

\subsection{Zorgconferenties}

In 2014 werden de eerste stappen gezet die zouden leidden tot het fenomeen de 'zorgconferentie' in de TBS. Tijdens een zorgconferentie komen medewerkers van het Ministerie van Justitie en Veiligheid, TBS-klinieken, externe deskundigen, terbeschikkinggestelden en TBS-advocaten samen om knelpunten te bespreken. Meestal staat de vraag centraal waarom de TBS lang duurt en of daar iets aan gedaan kan worden. Regelmatig zijn er verrassende uitkomsten. Zorgconferenties zijn intensief en vaak effectief. De uitkomst van een zorgconferentie kan een zwaarwegend advies aan de TBSkliniek zijn. In mei 2019 bespraken Peter Oosterom en Bert Bezemer - beiden verbonden aan de Dienst Justitiele Inrichtingen van het ministerie - en advocaat Job Knoester in Strafblad over opgedane ervaringen met zorgconferenties in het project ' 15 -plus'. ${ }^{12}$ Hierbij ging

9. Art. 17 lid 2 t/m 5 Verlofregeling.

10. Raad voor Strafrechtstoepassing en Jeugdbescherming 'Langdurig in de tbs': www.rsj.nl/binaries/rsj/documenten/rapporten/2020/05/18/knel punten-zorgen-voor-stagnatie-in-door--en-uitstroom-tbs-gestelden/RS」 +advies+Langdurig+in+de+tbs+20200430.pdf.

11. Commissie-Visser: https://zoek.officielebekendmakingen.nl/kst-302505.html.

12. P. Oosterom, B. Bezemer \& J.A.W. Knoester, 'Zorgconferenties in de tbs - ervaringen opgedaan in het project '15-plus', Strafblad 2019/15, p. 32-36. 
het om terbeschikkinggestelden die langer dan vijftien jaar de TBS-maatregel ondergingen.

Het ministerie heeft met TBS Nederland ${ }^{13}$ de zorgconferenties TBS 15-plus geëvalueerd. Dat heeft geleid tot een nieuwe organisatie per 1 maart $2020 .{ }^{14}$ Zorgconferenties kunnen nu worden georganiseerd als:

- termijnen die zijn afgesproken bij de manifesten van Lunteren in de knel (dreigen te) komen;

- resocialisatiepogingen zijn mislukt;

- een perspectief op uitstroom niet aanwezig is;

- er zich incidenten hebben voorgedaan;

- geen overeenstemming met de terbeschikkinggestelde kan worden bereikt; en

- conclusies uit het pro-Justitia onderzoek niet overeenkomen met het verlengingsadvies van de kliniek.

Zowel de TBS-kliniek, terbeschikkinggestelde als zijn advocaat kunnen bij het ministerie een zorgconferentie aanvragen. Ook de LAP-commissie die adviseert over hertoetsing van de LFPZ-status (vroeger longstay) en de TBS-verlengingsrechter kunnen het advies geven een zorgconferentie te organiseren. Het ministerie kan ook zelf het initiatief nemen, bijvoorbeeld naar aanleiding van een verlengingsadvies, een overplaatsingsverzoek, een verlofaanvraag, incidenten of andere bijzondere omstandigheden.

Het is niet de bedoeling dat lichtvaardig een zorgconferentie wordt georganiseerd. Bij voorkeur wordt eerst een aantal andere stappen doorlopen. In eerste instantie is dit een interne collegiale consultatie in de kliniek. Vervolgens kan een driegesprek met de terbeschikkinggestelde, zijn advocaat en de behandelaar worden gehouden. Als dit niet tot een oplossing leidt, kan nog een collegiale consultatie door een andere kliniek worden aangevraagd. Hierdoor kan indien nodig specialistische of niet forensische deskundigheid worden aangeboord. Als dat allemaal geen oplossing oplevert komt de zorgconferentie in beeld.

De intrede en uitbreiding van zorgconferenties vormen een versterking van de positie van de terbeschikkinggestelde, maar de uitkomst van de conferentie blijft slechts een (zwaarwegend) advies aan de kliniek. Ook na een zorgconferentie heeft een terbeschikkinggestelde geen podium waar hij dwingend kan laten toetsen of de kliniek op het juiste spoor zit als het gaat om de inhoud van de behandeling. De TBS-verlengingsrechter heeft in feite slechts te oordelen over de vraag of de TBS en/of verpleging van overheidswege moet worden verlengd en zo ja, met een of met twee jaar.

13. www.tbsnederland.nl.

14. Brief van de Directeur Divisie Individuele Zaken d.d. 21 februari 2020 aan de ketenpartners in het TBS-veld: www.google.com/url? $\mathrm{sa}=\mathrm{t} \& \mathrm{rct}=\mathrm{j} \& \mathrm{q}=\& \mathrm{esrc}=\mathrm{s} \&$ source $=$ web $\& \mathrm{~cd}=\& \mathrm{cad}=\mathrm{rja} \&$ uact $=8 \& \mathrm{ved}=2 \mathrm{ah} U$ KEwjai_jQj9XrAhWQy6QKHdfLAOgQFjAAegQIBBAB\&url=https \%3A \%2F\%2Fwww.forensischezorg.nl\%2Fkennis-delen \%2Fnieuws \%2F organisatie-zorgconferenties-2020\&usg=AOvVawOAAtqGowbJ9f__ n1M3y1E.
De rechtspraak hanteert de hoofdregel dat de TBS met twee jaar wordt verlengd als ervan moet worden uitgegaan dat de behandeling nog meer dan een jaar nodig heeft. ${ }^{15}$ In bijzondere gevallen wijkt de verlengingsrechter hiervan af en wordt de TBS toch met een jaar verlengd. Aldus ontstaat dan toch enige bemoeienis met de inhoud van de behandeling, hetgeen de rechtspositie van de terbeschikkinggestelde ten goede komt. Een paar voorbeelden.

Op 27 augustus 2017 verlengde de rechtbank Amsterdam de TBS met één in plaats van twee jaar om een vinger aan de pols te houden. ${ }^{16}$ Hoewel de rechtbank ervan uitging dat de behandelduur nog meer dan een jaar in beslag zou nemen, wilde ze toch de flinke stappen die de terbeschikkinggestelde het komende jaar zou gaan zetten eerder kunnen toetsen.

Op 25 april 2019 oordeelde de rechtbank Overijssel over een gehospitaliseerd terbeschikkinggestelde. ${ }^{17}$ Ook hier ging rechtbank ervan uit dat de TBS nog langer dan een jaar zou duren. Er was geen twijfel of de kliniek de behandeling voortvarend zou voortzetten. Toch wilde de rechtbank, gelet op de bijzondere omstandigheden en de te verwachten ontwikkelingen, eerder dan na twee jaar de voortgang toetsen. De TBS werd met één jaar verlengd.

Op 30 april 2015 verlengde het gerechtshof ArnhemLeeuwarden de TBS met één jaar in plaats van twee jaren. ${ }^{18}$ Het hof nam expliciet in de overwegingen mee dat er onzekerheid bestond met betrekking tot een longstayplaatsing van de terbeschikkinggestelde. Daarbij werd betrokken dat bij verlenging met één jaar op korte termijn ter gelegenheid van de te verwachten nieuwe vordering tot verlenging onafhankelijk gedragskundig onderzoek zou moeten worden verricht.

Het gerechtshof Arnhem-Leeuwarden week op dezelfde dag, 30 april 2015, nog eens af van de hoofdregel, door de TBS met één in plaats van twee jaar te verlengen. ${ }^{19}$ In dit geval was er sprake van een net gewijzigde houding van de terbeschikkinggestelde ten aanzien van de behandeling en het medicatiegebruik. Het hof zag een broze commitment die mede gelet op de persoonlijkheidsproblematiek in stand moest worden gehouden. Het werd van belang geacht dat de verlengingsrechter eerder dan pas na twee jaar zich zou buigen over de vraag of de TBS zou moeten worden verlengd, waarbij de gevolgen van de libidoremmende medicatie en het omgaan met vrijheden buiten de kliniek zouden kunnen worden betrokken.

Op 4 mei 2016 zag het gerechtshof Arnhem-Leeuwarden eveneens reden af te wijken van het uitgangspunt te verlengen met twee jaar als aannemelijk is dat de

15. Vergelijk hof Arnhem 6 juni 2019, ECLI:NL:GHARL:2019:7412.

16. Rb. Amsterdam 27 augustus 2017, ECLI:NL:RBAMS:2017:6048.

17. Rb. Overijssel 25 april 2019, ECLI:NL:RBOVE:2019:1432.

18. Hof Arnhem-Leeuwarden 30 april 2015, ECLI:NL:GHARL:2015:3686.

19. Hof Arnhem-Leeuwarden 30 april 2015, ECLI:NL:GHARL:2015:3687. 
behandeling meer tijd nodig heeft dan één jaar. ${ }^{20}$ Het hof zag hiertoe aanleiding in het verloop van de behandeling, maar legde niet uit wat hiermee precies werd bedoeld. Wel werd overwogen dat ook met een jaar werd verlengd om op kortere termijn te kunnen toetsen of aan de voorwaarden voor een voorwaardelijke beëindiging van de dwangverpleging zou zijn voldaan. Door deze overweging kan de vraag worden gesteld of daadwerkelijk van het genoemde beleid werd afgeweken dat steeds moet worden verlengd met twee jaar als de behandeling nog meer dan één jaar in beslag neemt.

Van belang is ook nog de uitspraak van het gerechtshof Arnhem d.d. 17 januari 2011.21 Het hof liet de verlenging van de TBS van de rechtbank met één jaar in stand, maar vulde de gronden aan. Een patstelling in de behandeling moest worden doorbroken. De kliniek werd in overweging gegeven te onderzoeken of de reclassering bij de behandeling kon worden betrokken om het perspectief op resocialisatie te vergroten, ondanks dat dit niet gebruikelijk was in de fase waarin de behandeling zich op dat moment bevond. Het hof zag hiermee ruimte zich te bemoeien met de inhoud van de behandeling.

De intrede van zorgconferenties en het nieuwe beleid per 1 maart 2020 zijn een verbetering van de positie van de terbeschikkinggestelde. Om het vertrouwen van verdachten en terbeschikkinggestelden in de TBS-maatregel te vergroten, is het echter noodzakelijk dat een rechtsgang wordt gecreëerd waarmee terbeschikkinggestelden op gemotiveerde wijze knelpunten in de behandeling aan een onafhankelijke instantie kunnen voorleggen. Een dergelijke instantie zou vergelijkbaar kunnen zijn met de penitentiaire kamer van het gerechtshof of met de Raad voor Strafrechttoepassing en Jeugdbescherming. Rechters en gedragsdeskundigen maken deel uit van deze colleges. Een voorwaarde zou kunnen zijn dat, voordat een dergelijke rechtsgang mogelijk wordt, de terbeschikkinggestelde met zijn advocaat eerst de weg heeft behandeld van een driegesprek en zorgconferentie. Wanneer dat vervolgens niet tot een bevredigende oplossing heeft geleid, zou een definitief oordeel aan de onafhankelijke rechter kunnen worden gevraagd. Vanzelfsprekend kan een dergelijk oordeel zowel in het voor-als in het nadeel van een terbeschikkinggestelde uitvallen. Ook als de beslissing in het nadeel van de terbeschikkinggestelde uitpakt, zal zij wel duidelijkheid creëren en mogelijk daarmee ook een impuls kunnen geven om uit een eventuele behandelimpasse te geraken. Ook dat is van belang voor een goede doorstroming in TBS.

Bij vorenstaande is van belang dat verdachten die worden veroordeeld tot de maatregel van plaatsing in een inrichting voor stelselmatige daders (ISD) tussentijds aan de rechter (!) om een toets kunnen vragen van

20. Hof Arnhem-Leeuwarden 4 mei 2016, ECLI:NL:GHARL:2016:7506.

21. Hof Arnhem 7 januari 2011, ECLI:NL:GHARN:2011:BP3995. die maatregel. ${ }^{22}$ Als de rechter die ISD oplegt en niet zelf heeft bepaald dat een tussentijdse beoordeling op zijn plaats is, kan de veroordeelde daar zelf om vragen na zes maanden na aanvang van de ISD of na zes maanden na het onherroepelijk worden van de beslissing om niet tussentijdse toetsen of van de beslissing dat voortzetting van de tenuitvoerlegging van de ISD is vereist. Er moet van worden uitgegaan dat de wetgever heeft ingezien dat de ISD langere vrijheidsbeneming (twee jaar) inhoudt, waardoor het noodzakelijk is de waarde en kwaliteit van die maatregel tussentijds te beoordelen. Tegen die achtergrond is het onbegrijpelijk dat een dergelijke tussentijdse toets niet kan worden aangevraagd door een terbeschikkinggestelde. In eerst instantie duurt die maatregel twee jaar. Er zijn echter weinig terbeschikkinggestelden die korter dan acht jaar in een tbs-kliniek verblijven. TBS kan uiteindelijk zelfs levenslang duren.

\section{Perspectief of uitzichtloos? Het imagoprobleem van de TBS}

In het Nederlandse strafrecht geldt als ongeschreven uitgangspunt dat gestraft wordt naar de mate van schuld. Omdat de terbeschikkingstelling een (veiligheids)maatregel ${ }^{23}$ is, speelt dit beginsel geen rol bij het opleggen van de terbeschikkingstelling. ${ }^{24,}{ }^{25}$ De terbeschikkingstelling wordt opgelegd voor een periode van twee jaar (en kan daarna - telkens - met een jaar of met twee jaren worden verlengd). In artikel 38e lid $1 \mathrm{Sr}$ is bepaald dat de totale duur van de terbeschikkingstelling een periode van vier jaar niet te boven gaat. ${ }^{26} \mathrm{Er}$ wordt in datzelfde artikellid echter meteen een uitzondering op dit uitgangspunt gemaakt: '(...) tenzij de terbeschikkingstelling is opgelegd ter zake van een misdrijf

22. Art. 6:6:14 Sv.

23. Vgl. J. Remmelink, Mr. D. Hazewinkel-Suringa's Inleiding tot de studie van het Nederlandse Strafrecht, Arnhem: Gouda Quint 1994, p. 754: 'Het karakter (Enschedé spreekt van ethos) is ongetwijfeld medisch, het eigenlijke doel is echter maatschappijbeveiliging. In de MvA van de nieuwe regeling (TK 1980 - 1981, 11 932, nrs. 5 - 7, p. 4) wordt zulks (...) bevestigd.' Zie ook: art. 37 a lid $1 \mathrm{Sr}$, waarin de veiligheid als voorwaarde voorop wordt gesteld.

24. In de praktijk wordt bij de vraag of TBS moet worden opgelegd de zwaarte van de maatregel (proportionaliteit) wel meegewogen door de rechter. Zie bijvoorbeeld: hof Arnhem-Leeuwarden 12 december 2018, ECLI:NL:GHARL:2018:10933.

25. Vgl. J. Remmelink, a.w., p. 635: 'Bij de maatregel domineert de speciale preventie (...).'

26. Hof Arnhem-Leeuwarden 23 april 2020, ECLI:NL:GHARL:2020:3335: De maatregel eindigt van rechtswege wanneer de maximale termijn van vier jaar wordt bereikt. HR 18 februari 2020, ECLI:NL:HR:2020:282, NJ 2020/175, m.nt. Mevis: In de maximale duur van de TBS met verpleging is begrepen zowel (i) de duur van de voorwaardelijke beëindiging van de verpleging als (ii) in voorkomende gevallen - de periode waarin de verpleging voorlopig is hervat. In gevallen waarin sprake is van een gemaximeerde TBS met verpleging, eindigt deze van rechtswege uiterlijk na ommekomst van vier jaar, te rekenen van de dag waarop de betreffende uitspraak onherroepelijk is geworden. 
dat gericht is tegen of gevaar veroorzaakt voor de onaantastbaarheid van het lichaam van een of meer personen.'

Aan de verlenging van de terbeschikkingstelling met verpleging van overheidswege die is opgelegd in verband met een geweldsmisdrijf is geen plafond gesteld. Het belang van de bescherming van de maatschappij weegt in zo'n geval zwaarder dan het belang van de individuele terbeschikkinggestelde. Hierdoor kan de terbeschikkingstelling in theorie 'levenslang' duren. Voor veel verdachten en terbeschikkinggestelden is dit vooruitzicht een schrikbeeld. Verdachten zijn daarom vaak bang voor de oplegging van TBS en terbeschikkinggestelden raken - onder het motto: het heeft toch allemaal geen zin - nogal eens gedemotiveerd (wanneer de behandeling in hun ogen te lang duurt). Het gebrek aan perspectief en de uitzichtloosheid die wordt ervaren tijdens het behandeltraject, leiden ertoe dat in de praktijk niet altijd optimaal wordt geprofiteerd van de mogelijkheden van de terbeschikkingstelling. Verdachten die uit angst voor TBS weigeren mee te werken aan diagnostisch onderzoek, worden beoordeeld op basis van onvolledige en (vaak) oude informatie (art. 37a lid 4 en $6 \mathrm{t} / \mathrm{m}$ $9 \mathrm{Sr}){ }^{27}$ Terbeschikkinggestelden die de moed hebben opgegeven omdat ze het gevoel hebben niet vooruit te komen, lopen in hun behandeling (forse) vertraging op.

Een ander probleem vormen de combinatievonnissen of -arresten, waarin naast de TBS een zeer lange gevangenisstraf wordt opgelegd. ${ }^{28} \mathrm{Er}$ wordt in die gevallen als het ware een dubbel slot op de deur gezet om te garanderen dat de betrokkene maar zo lang mogelijk uit de vrije samenleving wordt verwijderd. Door de afschaffing van de zogenoemde Fokkens-regeling ${ }^{29}$ - die regelde dat de TBS-behandeling al na een derde van de straf kon beginnen - en het beperken van de duur van de voor-

27. Zie over deze problematiek: Conclusie A-G mr. Harteveld 9 februari 2016, ECLI:NL:PHR:2016:137. De A-G bespreekt onder meer het arrest van het EHRM in de zaak Constancia tegen Nederland (EHRM 3 maart 2015, nr. 73560/12, ECLI:NL:XX:2015:230, NJ 2015/282, m.nt. Myjer). In die zaak oordeelde het EHRM dat de rechter aan een weigerende observandus TBS kan opleggen op basis van niet-actuele medische informatie over de geestesgesteldheid, zonder in strijd te komen met art. 5 lid 1 en onder e, EVRM. Zie voorts: HR 7 april 2020, ECLI:NL:HR:2020:625, NJ 2020/160, over het gebruik van het PBCrapport over de reden van de weigering als 'een ander advies op rapport' als bedoeld in art. 37 lid $3 \mathrm{Sr}$ (oud).

28. Hofstee wees erop dat de wetgever destijds (begin jaren tachtig) uitdrukkelijk uitging van een terughoudend gebruik van de mogelijkheid om een straf op te leggen naast TBS: 'De MvT (p. 10) verschoof de straf zelfs naar het tweede plan: “(...) voor strafoplegging aan een verdachte (beter: dader, E.H.) aan wie de maatregel van terbeschikkingstelling wordt opgelegd, (kan) slechts plaats zijn voor zover die straf niet op onaanvaardbare wijze afbreuk doet aan het medische karakter van die maatregel en een goede therapeutische behandeling" (cursivering, E.H.). Zij plaatste dus het nuttig effect van de TBS, en niet de straf, op de voorgrond.'. E.H. Hofstee, TBR en TBS, De TBR in rechtshistorisch perspectief, Arnhem: Gouda Quint 1987, p. 514

29. Besluit van 24 juli 2010 tot wijziging van het Reglement verpleging ter beschikking gestelden wegens een technische aanvulling en tot wijziging van de Penitentiaire maatregel in verband met de schrapping van de bepaling dat de plaatsing van een veroordeelde die tevens de maatregel van tbs met dwangverpleging is opgelegd, in beginsel geschiedt nadat eenderde van de opgelegde gevangenisstraf ten uitvoer is gelegd en enige technische verbeteringen, Stb. 2010, 312. waardelijke invrijheidstelling tot maximaal twee jaar, ${ }^{30}$ moeten veroordeelden vaak lang in detentie verblijven voordat met de behandeling kan worden begonnen. Zo'n lange detentie draagt niet bij aan een vlotte en succesvolle TBS-behandeling. ${ }^{31,}{ }^{32}$ In wezen doet de rechter met een combinatievonnis of -arrest, waarin de TBS met een zeer lange gevangenisstraf wordt gecombineerd een innerlijk tegenstrijdige uitspraak. Enerzijds wordt met zo'n uitspraak benadrukt dat de betrokkene een effectieve behandeling zou moeten krijgen, maar anderzijds wordt een straf opgelegd die de kans van slagen van die behandeling bemoeilijkt en misschien wel onmogelijk maakt. Het zou (vanuit het doel dat met het opleggen van een straf of een behandeling is gediend beschouwd) veel logischer zijn wanneer de rechter in voorkomende gevallen een duidelijke keuze zou maken tussen langdurig straffen en behandelen. Wanneer 'vergelding' de nadruk verdient, past het opleggen van een forse gevangenisstraf. Maar wanneer 'speciale preventie' daarentegen de voorkeur heeft, zou voor TBS moeten worden gekozen. De beide strafdoelen gaan in de praktijk niet goed samen. Tegen het opleggen van een (betrekkelijk) korte gevangenisstraf in combinatie met TBS, bestaat veel minder bezwaar omdat dan minder gauw detentieschade optreedt.

Onder het motto 'safety first' wordt de TBS, zoals gezegd, vaak gecombineerd met een lange gevangenisstraf. ${ }^{33}$ Daarnaast neemt de gemiddelde duur van de TBS de laatste jaren steeds meer toe. ${ }^{34}$ Het is in zoverre niet vreemd dat verdachten en terbeschikkinggestelden

30. Wet Straffen en Beschermen, Stb. 2020, 224. Inwerkingtreding waarschijnlijk in het voorjaar van 2021.

31. De Taskforce behandelduur tbs wees in haar rapport uit 2014 (p. 20) onder andere op de mogelijke detentieschade die het gevolg zou kunnen zijn van een combinatievonnis. Zij adviseerde daarom terughoudend te zijn in het opleggen van lange gevangenisstraffen in combinatie met TBS en gaf de rechterlijke macht in overweging in het combinatievonnis of -arrest een advies op te nemen de behandeling eerder te laten beginnen. Daarnaast zou het aanbeveling verdienen om terbeschikkinggestelden tijdens de detentie beter voor te bereiden op en te motivering voor de behandeling in de FPC. Dit zou kunnen door hen in de laatste fase van de detentie in een PPC te plaatsen.

32. RSJ, Langdurig in de tbs, Stagnatie in de door-en uitstroom van ter beschikking gestelden, Den Haag, 2020, p. 10: 'Door een lange intramurale behandelduur kunnen patiënten gehospitaliseerd raken, hetgeen de resocialisatie extra bemoeilijkt. Hierdoor vormt de lange duur op zichzelf ook een factor die de door- en uitstroom belemmert en daardoor bijdraagt aan stagnatie.' Dit geldt voor de duur van de TBSbehandeling, maar ook voor de langdurige gevangenisstraf die steeds vaker aan de TBS voorafgaat (RSJ, Langdurig in de tbs, a.w., p. 19: 'Het deel van de gevangenisstraf dat voorafgaat aan de tbs-maatregel moet worden uitgezeten wordt door de hierboven genoemde ontwikkelingen steeds langer. Dit heeft een negatief effect op het behandelperspectief.').

33. Om de detentieschade nog enigszins te beperken wordt soms conform het bepaalde in art. 37b lid $2 \mathrm{Sr}$ in het vonnis een overweging opgenomen waarin de rechter een advies geeft aan de minister over het moment waarop de TBS zou moeten ingaan. Dit advies is niet bindend voor de minister. Een mooi voorbeeld treft men aan in het vonnis van de rechtbank Limburg van 30 juli 2020, ECLI:NL:RBLIM:2020:5621.

34. Uit het rapport van de RSJ, Langdurig in de tbs, a.w., p. 9, kan worden afgeleid dat voor de helft van de terbeschikkinggestelden de behandeling binnen acht jaar kan worden afgerond (mediane behandelduur), maar dat $50 \%$ van de terbeschikkinggestelden als 'langblijvers' moet worden aangemerkt. 
klagen over het gebrek aan perspectief en over de uitzichtloosheid van de maatregel. De lange duur van de TBS hangt waarschijnlijk mede ${ }^{35}$ samen met het gevoelen van de samenleving, de media en de politiek, dat terbeschikkinggestelden gevaarlijk zijn en gemakkelijk recidiveren. ${ }^{36}$ De TBS heeft wat dat betreft niet een geweldig goed imago. ${ }^{37}$ Het is de vraag of dit wel helemaal terecht is, aangezien de TBS een verhoudingsgewijs laag percentage recidivisten kent. Ongeveer 19\% recidiveert binnen twee jaar na de TBS met verpleging en 23\% na TBS met voorwaarden. Daarbij recidiveren respectievelijk $4 \%$ en $5 \%$ met zeer ernstige delicten. Het WODC constateert dat sinds het uitstroomjaar 2008 het gemiddelde aantal delicten per recidivist binnen twee jaar na de onvoorwaardelijke beëindiging van TBS met verpleging sterk is gedaald, van 2,7 naar 1,6, terwijl het percentage recidivisten min of meer constant is gebleven. ${ }^{38}$

Deze cijfers steken gunstig af ten opzichte van die met betrekking tot ex-gedetineerden en ex-JJI-pupillen. Het recidivepercentage (binnen twee jaar) van ex-gedetineerden (die in 2015 waren vrijgekomen) bedraagt $47 \%$ en van ex-JJI-pupillen (die in 2015 waren vrijgekomen) zelfs $63 \%{ }^{39}$

In de recidivecijfers kan geen argument gevonden worden om negatief te oordelen over de resultaten die met de TBS (kunnen) worden bereikt en geven zeker geen aanleiding om de TBS in voorkomende gevallen te combineren met een langdurige gevangenisstraf of om de maatregel tot in het oneindige te verlengen. De cijfers laten zien dat de TBS werkt en dat de maatregel significant bijdraagt aan het terugdringen van de kans recidive.

\subsection{Mogelijke verbeteropties?}

Gelet op het bovenstaande zou het wellicht een goed idee kunnen zijn de TBS en de combinatie van gevangenisstraf en TBS aan een maximale duur te binden. Zo zou de maximale duur van de maatregel gekoppeld kunnen worden aan het wettelijk strafmaximum. Hieronder zal worden ingegaan op de vraag in hoeverre dit een reële mogelijkheid is. Een andere optie zou kunnen zijn de executievolgorde om te draaien, zodat de veroordeelde ten aanzien van wie een behandelnoodzaak

35. Uiteraard geldt voor de categorie langdurig terbeschikkinggestelden dat de lange duur van de behandeling ook voor een belangrijk deel samenhangt met de specifieke kenmerken van deze patiënten waardoor ze moeilijk behandelbaar zijn. Zie: RSJ, Langdurig in de tbs, a.w., p. 10.

36. E.J. Hofstee, 'De TBS opnieuw bezien', in: E.J. Hofstee e.a. (red.), Kringgedachten, Opstellen van de Kring Corstens, Deventer: Kluwer 2014, p. 265. Zie voorts: RSJ, Langdurig in de tbs, a.w., p. 20-22.

37. Zie voor enige nuance: J. van Emmerik \& O. Maathuis, 'TBS en het beeld hiervan bij de Nederlandse bevolking', Sancties 2017/22, p. 178-187.

38. K. Drieschner, J. Hill \& G. Weijters, WODC, Cahier 2018-22, Recidive na tbs, ISD en overige forensische zorg, p. 10.

39. G. Weijters, S. Verweij, N. Tollenaar \& J. Hill, WODC, Cahier 2019-10, Recidive onder justitiabelen in Nederland, Verslag over de periode 2006 - 2018, p. 9. De tweejarige zeer ernstige recidiveprevalentie bedroeg in 2015 ten aanzien van ex-gedetineerden $6 \%$ en ten aanzien van ex-JJ-pupillen $17 \%$ bestaat, meteen wordt behandeld, waarna vervolgens de straf dient te worden ondergaan, waarbij de duur van de TBS-behandeling van de strafduur dient te worden afgetrokken. ${ }^{40}$

\subsection{Straf naar de mate van schuld}

In hun analyse van een aantal uitspraken van feitenrechters in 2012 kwamen Claessen en De Vocht tot de conclusie dat het adagium 'straf naar de mate van schuld' te onzent waarschijnlijk niet een keihard rechtsbeginsel is. ${ }^{41}$ Straftoemeting verlangt maatwerk van de strafrechter. De mate van schuld van de verdachte is (uiteraard) een factor van belang, maar ook andere factoren hebben invloed op de strafoplegging. ${ }^{42}$

TBS is - zoals gezegd - in de eerste plaats een veiligheidsmaatregel. De mate van schuld van de verdachte bepaalt niet de duur van de TBS. ${ }^{43,}{ }^{44}$ De (niet gemaximeerde) TBS geldt immers voor de tijd van twee jaar en kan (telkens) worden verlengd (art. 38d Sr). Bij de verlenging van de maatregel wordt met name gekeken naar het nog bestaande delictgevaar (lid 2) en niet naar de mate van schuld van de verdachte aan het zogenoemde indexdelict. Toch speelt de mate van schuld van de verdachte vaak wel indirect een rol van betekenis bij de oplegging van TBS. Hoewel de wetgever strikt genomen geen causaal verband verlangt tussen de gebrekkige ontwikkeling of ziekelijke stoornis van de geestvermogens

40. Vgl. Sancties op maat, Eindrapport van de Commissie TBS en Sanctietoepassing Geestelijk Gestoorde Delinquenten (Commissie-Fokkens), Ministerie van Justitie, Den Haag 1993. Het voorstel van de Commissie met betrekking tot de combinatie van de TBS met een lange gevangenisstraf werd destijds door de wetgever niet overgenomen. Zie: Kamerstukken II 1994/1995, 24256, nr. 3 (MvT). Hofstee wijst er in zijn proefschrift op dat het voorstel om de executievolgorde bij cumulatie om te draaien al eerder was gedaan door Brongersma (1963) en Enschedé (1964). Zie: E.J. Hofstee, TBR en TBS, Arnhem: Gouda Quint 1987, p. 512.

41. J. Claessen \& D. de Vocht, 'Straf naar de mate van schuld?', DD 2012, 63, p. 652-674: 'In zaken waarin de rechter vaststelt dat de verdachte verminderd toerekeningsvatbaar is en desalniettemin tot de oplegging van een gevangenisstraf besluit, dient op zijn minst duidelijk te worden gemaakt waarom de vrijheidsstraf nodig wordt geacht en of en, zo ja, in welke mate de verminderde toerekeningsvatbaarheid in verhouding tot eventuele andere factoren bij het bepalen van de hoogte van de straf in overweging is genomen. Zolang een deugdelijke motivering op dit punt ontbreekt, kan niet met zekerheid worden gezegd of de Nederlandse strafrechter zich bij de straftoemeting in dit soort zaken nu wel of niet laat leiden door het adagium 'straf naar de mate van schuld' (674). Vgl. De Hullu, Materieel strafrecht, 2018, IV.1.7 Straftoemeting.

42. Hierdoor is het onder omstandigheden mogelijk dat iemand zwaarder wordt gestraft dan op basis van (alleen) zijn schuld passend zou zijn. Vgl. J. Remmelink, a.w., p. 197 en p. 822. Als de rechter een vrijheidsstraf oplegt, dient de maat daarvan naar de stellige overtuiging van Hofstee in evenredige verhouding te staan tot de schuldmaat. De concrete schuld dient volgens Hofstee de uiterste grens van de strafmaat te bepalen. Zie: E.J. Hofstee, Van TBR naar TBS, Studiepockets strafrecht nr. 18, Zwolle: Kluwer 1989, p. 89.

43. E.J. Hofstee, 'Straf naar de mate van schuld?', in: Naar eer en geweten, Liber amicorum J. Remmelink, Arnhem: Gouda Quint 1987, p. 195-214. Zie ook: E.J. Hofstee, TBR en TBS, a.w., p. 516-526.

44. Vgl. Ch.J. Enschedé, Beginselen van strafrecht, bewerkt door C.F. Rüter \& S.A.M. Stolwijk, Deventer: Wolters Kluwer 1990, p. 159: 'Straffen zijn, wat hun maat en modaliteit betreft, in beginsel begrensd via de vergeldingsnotie door de ernst van het delict en de schuld van de dader; maatregelen worden niet door de vergeldingsnotie gereguleerd en kunnen dus de maat der vergelding te boven gaan.' 
en het misdrijf waarvoor de maatregel wordt opgelegd (art. 37a lid 1 onder $\left.1^{\circ} \mathrm{Sr}\right),{ }^{45}$ is de mate van toerekeningsvatbaarheid in de praktijk vaak wel van invloed op het antwoord op de vraag of TBS moet worden opgelegd (en bij de vraag of de TBS moet worden gecombineerd met een al dan niet langdurige gevangenisstraf). De schuld heeft in die gevallen vooral invloed op de beantwoording van de vraag of de dader gestraft moet worden en op de vraag welke straf in dat geval passend is. Het adagium 'straf naar de mate van schuld' biedt echter niet een doorslaggevend argument voor de stelling dat de TBS in alle gevallen gemaximeerd zou moeten zijn.

\subsection{Proportionaliteit}

Het proportionaliteitsbeginsel zou wellicht wel als argument kunnen dienen. Het is vaste rechtspraak van de penitentiaire kamer van het gerechtshof Arnhem-Leeuwarden dat naarmate de TBS langer duurt, er aanleiding is om meer gewicht toe te kennen aan de beginselen van proportionaliteit en subsidiariteit. ${ }^{46} \mathrm{Bij}$ afweging van de belangen van de terbeschikkinggestelde en van de maatschappij dient naar mate de maatregel van terbeschikkingstelling langer duurt, het belang van de terbeschikkinggestelde steeds zwaarder te wegen. ${ }^{47}$ Dit geldt in het bijzonder ook voor terbeschikkinggestelden die niet meer behandeld (kunnen) worden en om die reden in een longstay- of longcare-voorziening terecht zijn gekomen (waardoor zij het zicht op beëindiging van de maatregel nagenoeg of volledig zijn kwijtgeraakt). Dit wil uiteraard niet zeggen dat het proportionaliteitsbeginsel de verlengingsrechter dwingt om de maatregel van een terbeschikkinggestelde die in een longstay- of longcare-voorziening is geplaatst stante pede te beëindigen. Het beginsel dwingt de verlengingsrechter wel om (telkens) kritisch te blijven kijken naar de noodzaak van verdere verlenging van de maatregel en naar de mogelijkheden van uitstroom uit de TBS. ${ }^{48}$ De belangen van de terbeschikkinggestelde dienen door de verlengingsrechter te worden afgewogen tegen de belangen van de maatschappij. Naarmate de maatregel langer duurt, gaan de belangen van de terbeschikkinggestelde steeds zwaarder wegen:

'Het hof dient in het kader van procedures betreffende het verlengen van de TBS-maatregel te beslissen of het, gelet op het eventuele delictgevaar, noodzakelijk is dat de maatregel wordt verlengd. Daarbij moet mede in aanmerking worden genomen het tijdsverloop in relatie tot de ernst van het delict waarvoor de

45. 'Gelijktijdigheid' is voldoende. Zie: HR 13 maart 1979, NJ 1979/364, m.nt. Melai. Zie voorts: E.J. Hofstee, TBR en TBS, a.w., p. 127-131. Hofstee constateert dat naar de letter een causaal verband tussen de psychische stoornis en het strafbare feit niet verlangd wordt (p. 128), maar concludeert vervolgens dat de wetgever voor toepassing van de TBR wel is uitgegaan van een causaal verband tussen de psychische stoornis en de (geprognosticeerde) gevaarlijkheid van de dader (p. 131).

46. O.a. hof Arnhem 28 februari 2005, ECLI:NL:GHARN:2005:AV3034.

47. O.a. hof Arnhem 10 maart 2008, ECLI:NL:GHARN:2008:BC7521 en hof Arnhem-Leeuwarden 31 mei 2018, ECLI:NL:GHARL:2018:11354.

48. Hof Arnhem 5 maart 2007, ECLI:NL:GHARN:2007:AZ9806, NJ 2007/236 en hof Arnhem 6 juli 2010, ECLI:NL:GHARN:2010:BN0531. maatregel is opgelegd. Naarmate de terbeschikkingstelling langer duurt, gaan bij de afweging tussen de belangen van de maatschappij bij beveiliging en de belangen van de terbeschikkinggestelde de belangen van laatstgenoemde steeds zwaarder wegen. Daarbij nopen ook de eisen van proportionaliteit en subsidiariteit tot het zorgvuldig en met spoed onderzoeken van de vervolgmogelijkheden zodra de mate van delictgevaar dit toelaat. (...)

Het hof acht onder deze omstandigheden, gelet op artikel 5 van het Europees Verdrag tot bescherming van de rechten van de mens en de fundamentele vrijheden, gezien de ernst en de omstandigheden van het delict waarvoor de TBS-maatregel aan betrokkene werd opgelegd, het tijdsverloop sinds dit delict en gezien voormelde behandelgeschiedenis en de ontstane impasse met betrekking tot de verblijfplaats van betrokkene, dat er bij voortduring van de maatregel op de wijze zoals deze thans plaatsvindt, sprake is van strijd met de beginselen van proportionaliteit en subsidiariteit. Op grond hiervan dient de maatregel thans te eindigen. ${ }^{49}$

Bij de uitstroom uit de TBS kan tegenwoordig ook worden gedacht aan een civiele zorgmachtiging. ${ }^{50}$ Met het oog daarop kan de verlengingsrechter zijn beslissing voor ten hoogste drie maanden aanhouden teneinde zich nader te doen voorlichten omtrent de wijze waarop en de voorwaarden waaronder de terugkeer van de terbeschikkinggestelde in het maatschappelijk verkeer zou kunnen plaatsvinden. ${ }^{51}$

\subsection{Praktische bezwaren tegen een TBS-plafond}

Het grootste bezwaar tegen de introductie van een TBSplafond is dat er een categorie terbeschikkinggestelden is die zó extreem delictgevaarlijk blijft dat er voor hen geen reële mogelijkheid is om de overstap naar de reguliere geestelijke gezondheidszorg te maken en die door die delictgevaarlijkheid evenmin kan terugkeren in de vrije samenleving. Het is natuurlijk mogelijk om voor deze categorie een uitzondering te maken, maar het is de vraag of dat een wenselijke situatie oplevert. Er zal dan in ieder geval veel discussie ontstaan over grensgevallen.

Een ander bezwaar tegen een TBS-plafond is dat het gevaar bestaat dat de behandelmotivatie verdwijnt en dat terbeschikkinggestelden zeggen: 'Ik zit mijn tijd wel uit.' Van een gemaximeerde TBS gaat (voor de terbeschikkinggestelde) geen prikkel uit om voortvarend met de behandeling aan de slag te gaan. Een gevolg daarvan kan zijn dat de goede resultaten die met de TBS worden behaald als het gaat om het terugdringen van recidivekansen, verminderen. Daar zit uiteraard niemand op te wachten.

\footnotetext{
49. hof Arnhem 9 november 2010, ECLI:NL:GHARN:2010:BO4173.

50. Bijv. hof Arnhem-Leeuwarden 27 februari 2020, ECLI:NL:GHARL: 2020:2259

51. Art. 6:6:13 lid 6 Sv.
} 


\subsection{Praktische bezwaren tegen het omdraaien van de executievolgorde}

Naar aanleiding van het rapport Sancties op maat van de Commissie TBS en Sanctietoepassing Geestelijk Gestoorde Delinquenten (Commissie-Fokkens) heeft de minister destijds een aantal bezwaren opgesomd tegen het voorstel tot omkering van de executievolgorde. ${ }^{52}$ Een korte opsomming:

- Het voorstel kan ertoe leiden dat er in bepaalde gevallen wordt uitgeweken naar alleen een lange gevangenisstraf.

- Wanneer de veroordeelde anvankelijk weinig gemotiveerd is om an behandeling mee te werken, kan het aangewezen zijn om betrokkene ten minste de eerste tijd in een penitentiaire inrichting te laten verblijven.

- Het bestaan van een strafrestant zou kunnen leiden tot een verhoogd vluchtgevaar, omdat geen garantie bestaat dat het strafrestant niet behoeft te worden uitgezeten.

- Het voorstel verlangt een grotere betrokkenheid van de rechter bij de tenuitvoerlegging van de TBS en de gevangenisstraf.

- Er ontstaan (in de eerste jaren na invoering) problemen voor wat betreft de capaciteit omdat alle terbeschikkinggestelden met een combinatievonnis direct na het onherroepelijk worden van de uitspraak als TBS-passant worden beschouwd en binnen een redelijke termijn zullen moeten worden opgenomen.

De minister koos destijds daarom voor een andere oplossing: de zogenoemde 'Fokkens-regeling'. Nu deze regeling inmiddels weer van tafel is, kan de vraag worden gesteld in hoeverre de door de minister genoemde bezwaren tegen het omdraaien van de executievolgorde nog steeds gelden.

Zonder nu uitgebreid op de genoemde bezwaren in te gaan, durven wij te stellen dat deze bezwaren niet overtuigen. De minister schreef destijds al naar anleiding van het advies van de Commissie: 'Ook onderschrijf ik haar standpunt dat bij een combinatievonnis van TBS en lange gevangenisstraf, in beginsel de noodzaak tot behandeling vaststaat en er derhalve niet te lang gewacht dient te worden met de aanvang van de behandeling. ${ }^{53}$ Die noodzaak om zo spoedig mogelijk met de behandeling te beginnen bestaat heden ten dage nog steeds.

\section{Afronding: aanbevelingen voor het wegnemen van een aantal van de eerder geconstateerde problemen en verbeterpunten ${ }^{54}$}

\subsection{Combinatie gevangenisstraf en TBS}

In verband met de mogelijke detentieschade als gevolg van een zeer lange gevangenisstraf (voorafgaand aan de noodzakelijk geachte behandeling in het kader van de TBS), valt er veel voor te zeggen de oude 'Fokkensregeling' weer opnieuw in te voeren. Second best is de optie dat rechters vaker - het liefst in alle gevallen - een advies als bedoeld in artikel $37 \mathrm{~b}$ lid $2 \mathrm{Sr}$ in hun vonnis of arrest opnemen en daarin uitdrukkelijk vastleggen dat de tenuitvoerlegging van de maatregel na een derde van de straf of zo nodig nog eerder zou moeten aanvangen. Met het inwerkingtreden van de nieuwe VI-regeling zal het belang van een dergelijke overweging alleen maar toenemen.

De beste 'oplossing' is natuurlijk nog altijd dat in voorkomende gevallen wordt afgezien van het opleggen van een lange gevangenisstraf naast TBS.

\subsection{Passantenproblematiek}

De passantenproblematiek kan alleen worden opgelost als er iets aan de doorstroom in het TBS-traject wordt gedaan. Met het bouwen van nieuwe klinieken en het aantrekken van extra personeel kan de druk op het systeem wellicht enigszins worden verminderd, maar de grootste winst is toch te behalen in de uitstroom van terbeschikkinggestelden. Dit betekent dat er vooral geïnvesteerd moet worden in een (nog) meer efficiënte behandeling en in goede vervolgvoorzieningen (zonder wachtlijsten). Daarbij kan het helpen wanneer TBS-verlengingsrechters nog kritischer dan nu het geval is, kijken naar het behandelverloop en in hun verlengingsbeslissing overwegingen opnemen die zien op de voortgang in de behandeling van de terbeschikkinggestelde. Wanneer in de TBS geen vooruitgang meer geboekt kan worden, zal eerder gekeken moeten worden naar de mogelijkheid van voorwaardelijke beëindiging van de verpleging of zal sneller moeten worden aangedrongen

54. Na afronding van dit artikel verscheen een tweetal rapporten van de Inspectie Justitie en Veiligheid over de tenuitvoerlegging van de TBSmaatregel: Inspectie J\&V, Geen kant meer op kunnen. Een onderzoek naar de knelpunten en dilemma's in de resocialisatie van tbs-gestelden, 2020; en Inspectie J\&V, Incidentenonderzoek FPC de Oostvaarderskliniek 2019, 2020. In de brief van 14 oktober aan de Tweede Kamer (Kamerstukken I/ 2020/21, 29452, 239, 3058439) gaat de Minister in op de aanbevelingen die door de inspectie zijn gedaan. De Minister staat o.a. stil bij de belemmeringen in de door- en uitstroom. Hij kondigt onder meer aan te gaan investeren in vervolgvoorzieningen, waardoor de druk op de capaciteit zou kunnen afnemen. Daarnaast is hij ervan overtuigd geraakt dat maatwerk belangrijk is in de TBS. Met het oog daarop is hij voornemens om de (generieke) Teeven-maatregel af te schaffen. 
op een soepele overgang naar de reguliere geestelijke gezondheidszorg.

\subsection{Personeelsproblemen}

Het verloop van personeel binnen behandelteams is een probleem dat primair door de klinieken zelf (en door het ministerie) zal moeten worden opgelost. De sfeer op het werk en de werkdruk die medewerkers ervaren, zijn direct van invloed op hun functioneren. Daarnaast kunnen klinieken medewerkers aan zich binden door hen vaste contracten aan te bieden, royaal te belonen, en carrièremogelijkheden te bieden.

\subsection{Stilstand na incident}

Het zogenoemde 'Teeven-jaar' kent meer nadelen dan voordelen. Het leidt er niet toe dat terbeschikkinggestelden niet de fout in (zullen) gaan en zorgt voor veel spanning en frustratie (wat niet bijdraagt aan een effectieve behandeling). De oplossing is simpel. Laat het in alle gevallen aan het behandelteam over om te reageren op incidenten. Het team kan het beste beoordelen of het (nog) verantwoord is om door te gaan met het praktiseren van verloven en of de behandeling naar aanleiding van het incident dat heeft plaatsgevonden anders zou moeten worden vormgegeven. Het ministerie staat daarvoor te veel op afstand.

\subsection{Imagoverbetering en perspectief voor de terbeschikkinggestelde}

Het imagoprobleem dat kleeft aan de TBS als zodanig laat zich niet eenvoudig oplossen. Verdachten en terbeschikkinggestelden moeten het gevoel krijgen dat ze baat (kunnen) hebben bij een op maat gesneden behandeling en vooral ook dat een TBS-traject geen uitzichtloze weg is die, als het tegenzit, tot levenslange verwijdering uit de samenleving zal leiden. De samenleving (en de politiek) zal op haar beurt overtuigd moeten raken van de voordelen van een TBS-behandeling boven een 'kale' opsluiting. Een goede informatieverstrekking aan beide groepen kan bijdragen aan verbetering van het imago van de TBS.

Daarnaast zal er blijvend geinvesteerd moeten worden in de kwaliteit van de TBS-behandeling en in goede vervolgvoorzieningen (inclusief toezicht en terugvalpreventie).

Of het stellen van een plafond aan de behandelduur de oplossing is voor het probleem van de 'uitzichtloosheid' die soms wordt ervaren, is de vraag. Het omkeren van de executievolgorde lijkt daarentegen wel een bijdrage te kunnen leveren aan de effectiviteit van de behandeling en biedt daarnaast ook perspectief aan de terbeschikkinggestelde. Het lijkt ons zinvol deze 'oplossing' nader te onderzoeken en zo mogelijk in te voeren. 